\title{
Terms and Abbreviations
}

aktivnost' independent initiative

batrak hired rural laborer

bedniak poor peasant

burzhui bourgeois; derogatory term for members of formerly privileged classes

Cheka Extraordinary Commission for the Struggle with Counterrevolution and Sabotage, the national political police from 1917 to 1922 , succeeded by GPU

chony special assignment detachments, crack fighting units made up of party members and sympathizers

Council on Labor and Defense (STO) superseded Defense Council in April 1920

Defense Council Council of Worker-Peasant Defense, formed in November 1918 to coordinate mobilization tasks in civilian economy and military

Democratic Centralists a dissident party faction that protested the bureaucratization of the party

dvoenachalie dual command, the practice of requiring soldiers to obey an order only if it bore the signatures of both commander and commissar

edinonachalie one-man or unified command, in the hands of a commander who had proven his political reliability

fel'dsher military medical personnel; orderly

Glavpolitprosvet Main Committee for Political Enlightenment gosudarstvennost' stateness, consciousness of state power

GPU State Political Administration, national political police and security service from 1922 to 1934 , succeeded by NKVD 
GUVUZ Main Administration of Military Educational Institutions

khvostizm tail-endism, Bolshevik party term applied to members who allowed the popular mood to determine their stance, as opposed to staking out a position in advance of the masses

komandy obsluzhivaniia service units for disfranchised persons kombed committee of the rural (village) poor

Komsomol Young Communist League

krai administrative unit

krugovaia poruka collective responsibility, especially in the village, with specific reference to tax obligations and conscription

kulak wealthy peasant; often used as a general term of opprobrium for a person who exhibited exploitive or disagreeable behavior

kul'turnichestvo Russified version of kulturtregerstvo, a prerevolutionary movement among the intelligentsia to bring culture to the masses; adjective, kul'turnicheskii

kul'turniki cultural workers attached to army political departments KVR L. D. Trotskii, Kak vooruzhalas' revoliutsiia, 3 vols. (Moscow, 1923-1925)

mestnichestvo local patriotism, protection of local interests against central demands

Military Opposition a dissident party faction that disagreed with Trotsky's policies on the army at the Eighth Party Congress (1919)

Military Organization Bolshevik party agency to conduct political work in the Imperial Army

military specialists former officers of the Imperial Army who served in the Red Army

MOPR International Organization for Aid to Imprisoned Fighters for the Revolution

mushtra, mushtrovka harsh military discipline

Narkompros People's Commissariat of Enlightenment

NKVD People's Commissariat of Internal Affairs

obkom (oblastnoi komitet) regional committee of Bolshevik party

Osoaviakhim mass organization to disseminate knowledge about and promote support for military values, aviation, and chemistry

osobyi otdel special department, an agency of the Cheka operating in the Red Army

partizanshchina guerrilla warfare

politotdel political department

politprosvety departments of political enlightenment, local organs of Glavpolitprosvet

politruk (politicheskii rukovoditel') instructor in an army political department

politustav political manual, handbook of minimal required knowledge about political life and party history 
PPR I Partiino-politicheskaia rabota v Krasnoi Armii (aprel' 1918fevral' 1919): Dokumenty (Moscow, 1961)

PPR II Partiino-politicheskaia rabota v Krasnoi Armii (mart 19191920 gg.): Dokumenty (Moscow, 1964)

PPR III Partiino-politicheskaia rabota v Krasnoi Armii: Dokumenty, 1921-1929 (Moscow, 1981)

PPR IV Partiino-politicheskaia rabota v Krasnoi Armii: Dokumenty, iiul' 1929 g.-mai 1941 g. (Moscow, 1985)

Proletkul't Proletarian Culture, an organization and movement to bring culture to the working masses, under the aegis of the Commissariat of Enlightenment

Provisional Government the coalition government that formed after the fall of the Romanov dynasty and claimed power between March and November 1917

PSS V. I. Lenin, Polnoe sobranie sochinenii, 5th ed., 40 vols. (MosCow, 1958-1965)

PUR Political Administration of the Revolutionary Military Council of the Workers'-Peasants' Red Army

raion administrative unit

Red commanders mostly noncommissioned officers of the Imperial Army who were promoted to command rank during the Civil War

Red Guards urban and worker militias, usually attached to a factory or group of factories

revkom revolutionary committee, an organ of martial law set up by an army political department after reoccupation of territory that had fallen into White hands

RVS Revolutionary Military Council of the USSR

RVSR Revolutionary Military Council of the Republic, supreme organ of martial law during the Civil War, later renamed Revolutionary Military Council of the USSR (RVS)

smychka worker-peasant alliance or link (the political arrangement of the Soviet constitution)

Sovnarkom Council of People's Commissars

SP Sputnik politrabotnika (Moscow journal)

SR Socialist Revolutionary party

TEO Theater Department, Commissariat of Enlightenment

Tsentrokomdezertir Central Commission for the Struggle with Desertion

voenkor military correspondent, part of a mass movement to involve soldiers in newspaper activities

volost' rural administrative unit

Vsebiurvoenkom All-Russian Bureau of Military Commissars

Vsevobuch Universal Military Training Administration

VSNKh Supreme Council of the National Economy 
VTsIK All-Russian Central Executive Committee, executive organ of Congress of Soviets

Workers' Opposition dissident party fraction opposed to state control of trade unions 
SOLDIERS IN THE PROLETARIAN DICTATORSHIP 
